\title{
The Impact of External Threats to the Economic Security of the Business
}

\author{
Svitlana Onyshchenko \\ Doctor of Economics, Professor at the \\ Department of Finance and Banking, \\ Poltava National Technical Yuri \\ Kondratyuk University \\ Poltava, Ukraine \\ http://orcid.org/0000-0002-9660-1921
}

\author{
Oleksandra Maslii* \\ PhD in Economics, Associate Professor \\ at the Department of Finance and \\ Banking, Poltava National Technical \\ Yuri Kondratyuk University \\ Poltava, Ukraine \\ http://orcid.org/0000-0003-2184-968X
}

\author{
Bogdan Ivanyuk \\ Graduate student at the Department of \\ Finance and Banking, \\ Poltava National Technical Yuri \\ Kondratyuk University \\ Poltava, Ukraine \\ bivaniuk@chamber.ua
}

\begin{abstract}
The external environment of doing business in Ukraine is analyzed in the article. Immediate external threats to the economic security of the business are identified. Dependence of the level of business economic security on the country's shadow economy and corruption level was installed. The main tasks of building system of business economic security taking into consideration the impact of external threats are highlighted.
\end{abstract}

Keywords-economic security, business security, external threats, doing business, shadow economy, corruption.

\section{INTRODUCTION}

Nowadays, business in Ukraine is undergoing numerous tests, due to the migration of able-bodied population, reduction of gross fixed capital formation, inflation growing, crisis of public finances and banking system, capital outflow, considerable debt dependence and aggravation of social tension. The need for a detailed study of the threats to the economic security of business is of particular urgency in view of the achievement of the priority goals of state modernization, creation of a favorable business environment, enhancement of national competitiveness and improvement of the well-being of the country citizens.

Solving this problem requires a comprehensive approach to timely identification of the existing and potential threats to the economic security of the business, the prevention of which will have a decisive impact on the recovery of economic growth, formation of favorable business environment, enhancement of the competitiveness and overall viability of the national economy.

\section{RESEARCH RESULTS}

Studying the threats to the economic security of the business serves as the basis for developing and implementing in the public administration the measures to prevent and counteract threats of internal and external origin.

In a broad sense, threat is represented by factors and phenomena that endanger the interests of the state, society, business and the individual.

In particular, threat to the business security is suggested to be defined as a potential or a real event, action, process, factors or conditions that impede and / or making impossible the functioning and the development of a business and can lead to the termination of the economic activity.
Most often, from the standpoint of ensuring the economic security of a business, threats are classified as permanent or temporary, as well as external or internal [1].

According to general security theory [2], [3] five basic threats are distinguished:

- competition-related threats;

- human-related threats;

- threats related to the activities of the state (in relation to corruption, stimulation of export or domestic market, stimulation or suppression of demand, lobbying the interests of certain branches, imperfection of legislation, bureaucratization of economic relations, tax policy, etc.);

- $\quad$ organized crime threats;

- threats related to man-made and natural factors.

Often, a company begins to think about its security only after serious problems and financial losses have occurred.

Business security has different principles and approaches to management, and each approach has its own theory and concept. Their own methods, procedures and mechanisms are developed [4].

The aim of economic security of business as a direction in management is the condition of business existence, which achieves the optimal state of protection against risks and threats in all functional areas of activity. Its mission is to develop and implement measures aimed at protecting the business from threats to the internal and external environment.

In the concept of economic security of business formulating it is necessary to distinguish clearly two factors of influence: the threat of influence and the threat of harming the economy of the enterprise. In the concept of anti-crisis management - it is the impact, causing real damage to the economy of the enterprise. It does not exclude the possibility of escalation of the threat of influence into the very impact that caused real damage.

The concept of economic security of the business is aimed at ensuring the normal and stable business activity and is defined as the level of security of all systems of functioning in business activities carrying out and business relationships developing. An effective mechanism for managing the business economic security system 
establishing allows analyzing dangers, threats and risks. The purpose of such analysis is to identify the sources and causes of dangers, threats and risks and the causes of their occurrence.

Business concepts are evolving, like global economic and political trends, the external environment is constantly changing, and together with it the micro-environment of business structures is a prerequisite for their successful functioning, which is achieved by a restructuring led by one or several business concepts relevant to ideology, strategic orientation and specific features of the entity [5].

External business threats exercise a direct influence and determine the conditions of business operation and development. They are related to the activity of the state and the state policy of economic activity regulation, especially to the presence of such institutional deformations as: shadowing, corruption, raiding, economic crime, lobbying the interests of certain branches, imperfection of legislation, bureaucratization of economic relations, etc.

The business environment can be divided into two components: the direct-impact environment and the indirectimpact environment. Consumers, suppliers, resellers, and competitors are usually considered to be the direct impact environment. The environment of indirect influence includes the economic, political situation, socio-demographic, natural, legal, technical and technological component of the environment.

Most often, the environment of indirect influence determines management decisions aimed at the formation of goals, strategies and tactics of the organization. However, it is important to keep in mind and realize in practice that each of the components of the general environment of indirect influence in a particular situation can affect not only management technologies but also the very existence of a business.

To assess the environmental indirect impact of the business environment, the World Bank annually ranks 190 countries according to the Ease of Doing Business Index [6], based on ten internal indicators (business registration, building permits, connection to the power supply system, property registration, lending, investor protection, taxation, international trade, contract enforcement, insolvency settlement). Thus, the results of a comparative analysis of the ease of doing business in different countries in 2019 are presented in Figure 1.

In 2019, Ukraine improved its position by 5 points and ranked 71st among 190 surveyed countries (against 76th in 2018), ranking between Kyrgyzstan and Greece. The improvement of the external environment of doing business in Ukraine in 2019 happened due to the revival of international trade (increase of 41 positions in the rating), improvement of ensuring the fulfillment of contracts (increase of 25 positions in the rating), increase of investor protection level (increase of 9 positions in the rating), simplification of the procedure for building permits obtaining (increase of 5 positions in the rating), regulation of financial solvency at the legislative level (increased by 4 position in the ranking), simplicity the registration procedure of ownership (increased by 1 position in the ranking).

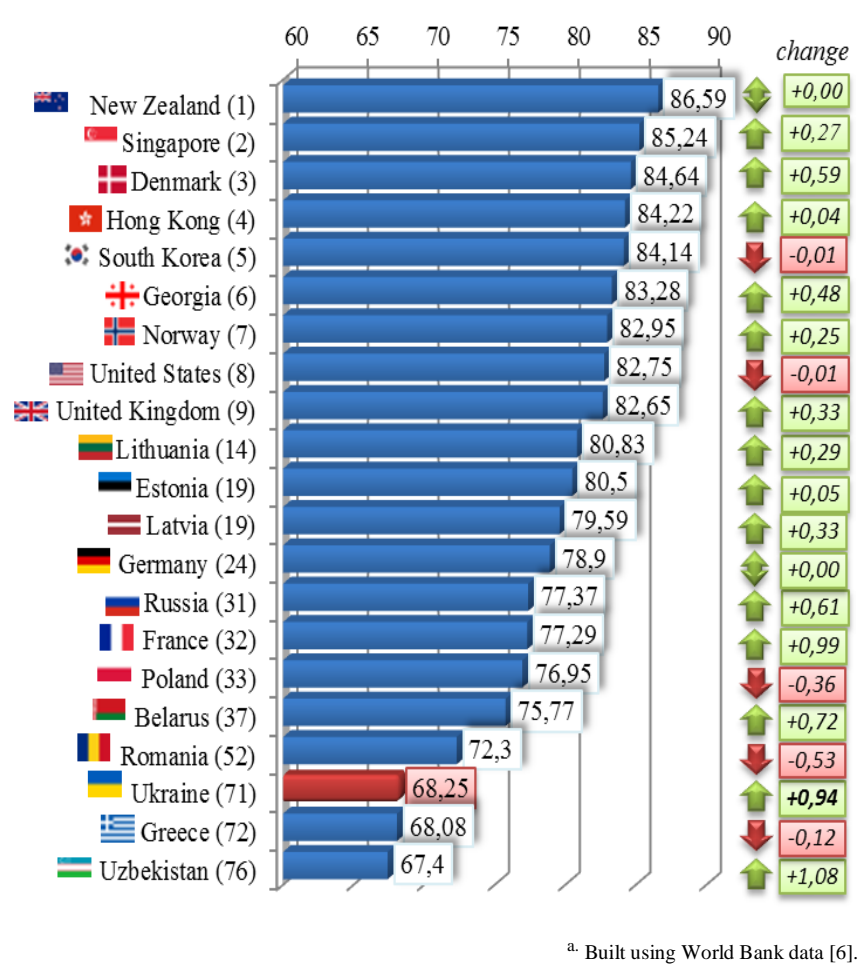

Fig. 1. Rank of countries by ease of doing business in 2019.

The dynamics of Ukraine's rating by ten indicators of ease of doing business in 2017-2019 are shown in Table 1.

TABLE I. RATING OF UKRAINE BY COMPONENT OF EASE OF DOING BUSINESS IN 2017-2019

\begin{tabular}{|l|c|c|c|c|}
\hline \multirow{2}{*}{ Components } & \multicolumn{3}{c|}{ Rating place } & Changes \\
in 2019
\end{tabular}

The main threats to the external environment of doing business in Ukraine today are related to excessive tax pressure and problems of taxation (deterioration by 11 positions in the rating), lack of reforms in the sphere of electricity (deterioration by 7 positions in the rating), complexity of business registration procedure (deterioration by 4 positions in the rating) and the difficulty of getting loans due to the crisis of the banking system (deterioration by 3 positions in the rating). 
Financial stability in the country and the general macroeconomic situation directly determine the conditions for doing business [7]. According to the results of 2018 and the beginning of 2019, a number of reforms have been made for the ease of doing business [8], [9]; however, the fundamentality and magnitude of the actual problems in the national economy of Ukraine, associated with the shadowing and corruption of all spheres of economic relations, significant changes in the functioning of the financial system during 2014-2019 due to excessive debt and inflationary pressure significantly actualize the problems of economic security of business and counteracting environmental threats.

One of the urgent threats to the economic security of a business with the maximum level of negative impact in the current environment is the existence of public debt and its sum, which is presented in Figure 2.

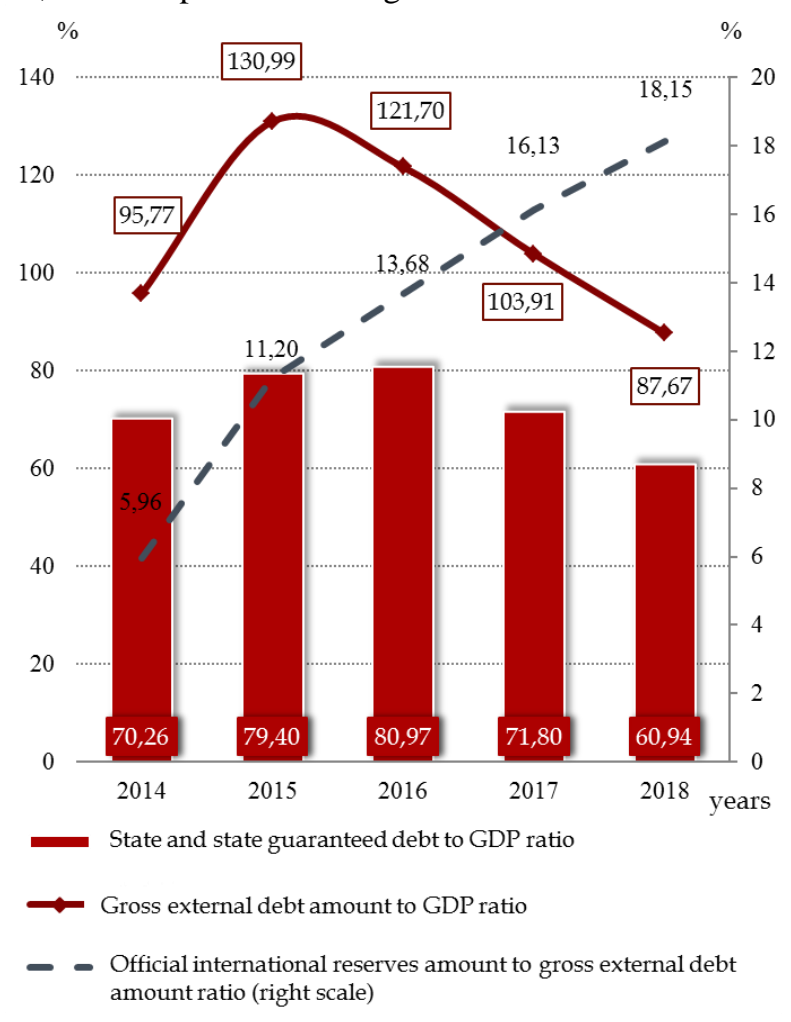

c. Compiled using data of the State Statistics Service of Ukraine [10].

Fig. 2. Dynamics of Indicators of Debt Threat to Economic Security of Ukraine's Business in 2014-2018.

It is worth noting that the increase of public debt in developed countries precedes economic growth, but world experience also demonstrates numerous examples of accumulation of public debt, which leads to an excessive increase in government borrowing [11]. It is worth noting the problem of settlement of state obligations in the context of the structure of internal and external state debt of Ukraine. Thus, addressing the issue of debt inefficiency is one of the most important issues facing the government in the current conditions of the country's development [12].

What can be mentioned here are the weak debt security of the state, its dependence on foreign capital and the independence of the Ukrainian economy. However, in 2018, the situation started to improve, with three of the five debt security indicators used by the Ministry of Economic Development and Trade of Ukraine [13] being improved compared to previous years, and most indicators starting to return to normative values after the protracted crisis.

At the same time, an important issue is the state budget deficit, so the approach of deficit financing of expenditures is common in Ukraine. Budget deficit often appears to be an article that covers the lack and imperfection of fiscal revenues when implementing a national socio-economic development strategy. The deficit to the state budget ratio is within the normal range, but in 2014 it was close enough to the critical value of $-6 \%$. Increasing the financial instruments of the state, the budget deficit also leads to many potentially negative consequences, and requires a comprehensive approach to managing the budget balancing process based on an in-depth study of factors.

What is also worth to be noted is the threatening magnitude of the shadow economy, which is primarily related to the shortcomings of the banking and legal systems that allow the legalization of criminal proceeds. The latest reorganization should provide new stabilization mechanisms that will provide capital formation, maintain sufficient level of liquidity and reserves to cover the risks of active operations stimulate the introduction of innovations as a basis for banks' efficiency and competitiveness.

In terms of monetary security, such indicators as the difference between interest rates on loans and deposits and the share of consumer loans to households in the overall structure of loans are satisfactory, as shown in Figure 3.

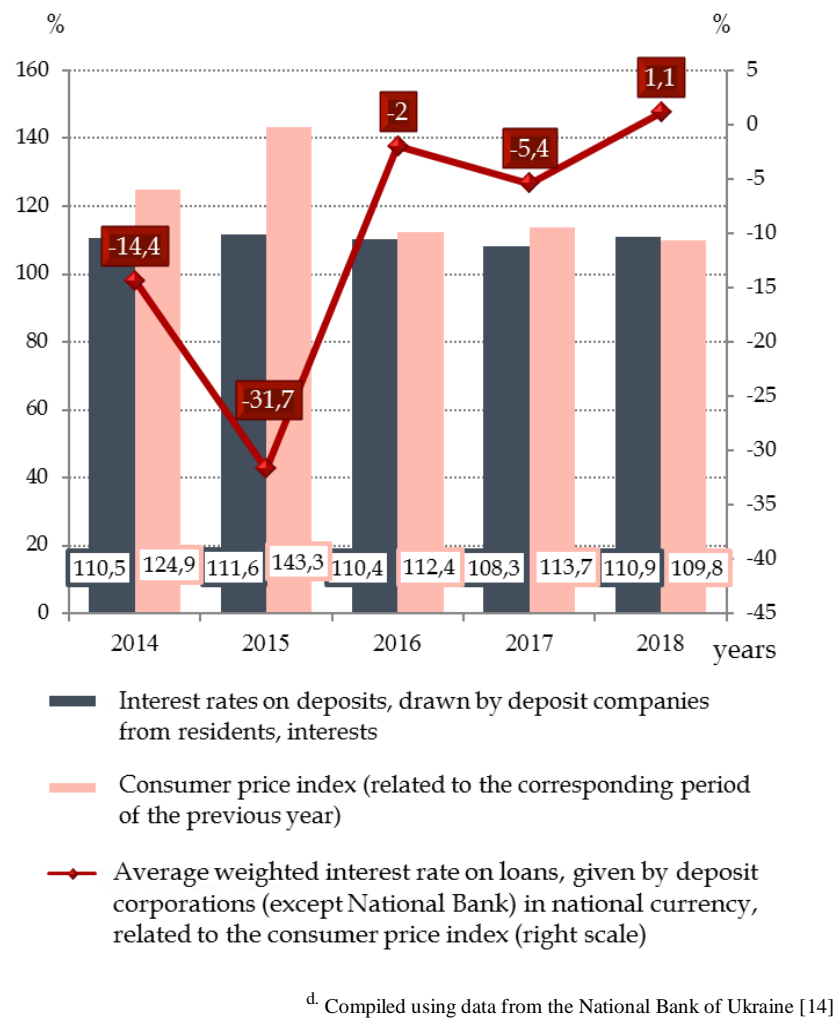

Fig. 3. Dynamics of indicators of threats to economic security of business in the monetary sphere of Ukraine in 2014-2018.

The average weighted interest rate on loans granted by deposit-taking corporations in national currency relative to 
the consumer price index has improved significantly compared to the base year, from $-24.9 \%$ to $1.1 \%$, so the level of lending and the price of financial resources is satisfactory. In terms of other indicators, the share of cash outside banks is lower than the threshold, but still unsatisfactory, though the decline from $28.45 \%$ to $20 \%$ is not possible at the current stage of development of digital economic infrastructure, so the period of 2014-2017 marked the improvement of the situation with the amount of cash, but in 2018 this indicator showed a negative trend. At the same time, the share of longterm loans in total volume deteriorated to $23.77 \%$ in 2018 , against the normative value of $25 \%$.

Thus, the monetary situation in Ukraine is generally unsatisfactory, with most indicators balancing at the marginal level, indicating problems in cash flow efficiency, attracting funds from economic entities to the banking system, and economic slowdown.

The process of upgrading the banking system already has its results, but they still have little effect on improving the ease of doing business, and a number of threats related to financial instability and too low level of development of the Ukrainian stock market [15] are catalysts for a number of challenges to the economic security of business.

The scales of the shadow economic crime do not only present a significant threat to the economic security of the business, especially for foreign investors, but also pose a real threat to the national security and democratic development of the country and adversely affects all spheres of public life. The presence of a shadow economy outside the limit of $30 \%$ of GDP according to official statistics [16] indicates the presence of real external threat to economic security business.

Corruption is one of the most pressing social and economic problems of today, and for Ukraine it has become a factor that really endangers the constitutional order of the state. Ukraine received 32 points out of 100 - two more than in 2017 and ranking 120th among 180 countries according to the 2018 Corruption Perceptions Index reported by Transparency International [17]. As previously stated [18], the contradictions in the political system represented by the combination of power and business have led to the strengthening of the oligarchy and not only lobbying the interests of businessmen in power through the adoption of the necessary laws in order to create favorable conditions for their business, but also to the shortfall of huge funds by the state treasury.

In order to substantiate the significant factors influencing the level of economic security of a business, it is important to investigate the sensitivity of the integral indicator of economic security to the changes of the relevant indicators. To evaluate the interdependencies between economic security indicators correlation analysis is used. Each index $\mathrm{x}_{\mathrm{ij}}$ corresponds to a normalized index $\mathrm{a}_{\mathrm{ij}}$. Let us determine the correlation coefficients between the normalized indicators and the integral index of business economic security by the equation (1).

$$
r=\frac{n \cdot \sum a_{i j} I-\sum a_{i j} \cdot \sum I}{\sqrt{\left[n \cdot \sum a_{i j}{ }^{2}-\left(\sum a_{i j}\right)^{2}\right] \cdot\left[n \cdot \sum I^{2}-\left(\sum I\right)^{2}\right]}},
$$

where $a_{i j}$ - indicators of threats to the economic security of a business in the relevant field; I - integral index of economic security of the business. Let us check the significance of the correlation coefficients using Student's ttest. To do this, we calculate the actual values of the Student's t-test for each correlation coefficient by the formula (2).

$$
t=r \sqrt{\frac{n-2}{1-r^{2}}}
$$

where $\mathrm{r}$ is the correlation coefficient, $\mathrm{n}-$ the amount of initial data. Those correlation coefficients for which the actual criterion values are not less than the critical values corresponding to a confidence probability of 0.95 and the number of degrees of freedom PT-2 $=23$ are considered significant. Among the indicators of the threats to the economic security of the business there should be distinguished the indicators for which the correlation coefficients between the relevant normalized indicators and the integrated assessment of the economic security of the business are of maximum value.

It has been established that the assessment of the economic security of the business is significantly related to the estimates of the country's shadow economy and corruption level. A graphical representation of the dependence of the integrated assessment of business economic security on the most significant indicators, which are the indicators of threats with the maximum level of impact, is given in Figure 4.
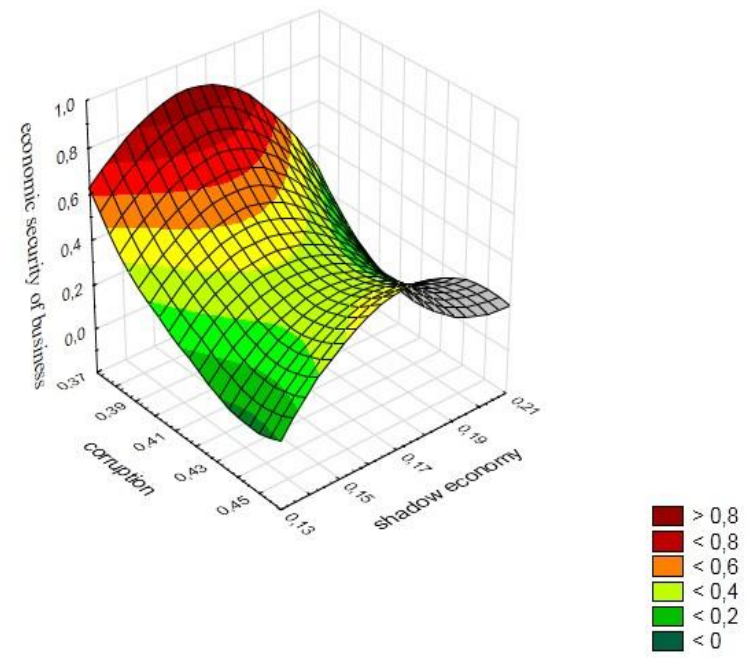

Fig. 4. Dependence of the level of economic security of business on the country's shadow economy and corruption level.

The results of evaluating the impact of identified threats on integral indicator of business economic security found that complex influence of detected threats led to a decline in economic security of a business. This is accompanied by a decline in innovation activity at all levels, an increase in tax pressure, complication of business registration procedure, difficulty of getting loans and a decrease in the competitiveness of the national economy, which makes it necessary to align state economic policy with the priority areas for ensuring economic security of business. 


\section{CONCLUSION}

Determining the impact of the external threats to the economic security of the business is the basis for developing measures to ensure it, that, in the context of the implementation of the socio-economic strategy of the state: in theory requires the development of an appropriate mechanism that would generally outline the system of elements and the links between them, aimed at the creation of safe conditions for the development of the state, and, in practical implementation - in public management of measures to prevent and counteract the threats to the economic security of the business, identification of the resources required, formation and use of the reserves.

\section{REFERENCES}

[1] S. Bank, V. Sekerin, A. Gorokhova, N. Nikolaykin, and A. Shcherbakov, "Risks and Threats Posed to a Company's Economic Security", International Journal of Engineering \&Technology (IJET), vol. 7, no. 3.15, pp. 210-215, 2018.

[2] D. Tyson, Security Convergence: Managing Enterprise Security Risk. Burlington, MA, USA: Butterworth-Heinemann, 2007.

[3] I. Kuznetsov, Business security. Moscow, Russia: Dashkov and K., 2012. [in Russian].

[4] Z. Varnaliy, S. Onishchenko, and A. Masliy, "Threat prevention mechanisms of Ukraine's economic security", Economic Annals-XXI, no. $159(5-6), \quad$ pp. 20-24, 2016 doi:http://dx.doi.org/10.21003/ea.V159-04. [in Ukrainian].

[5] A. Shumilova, "Benchmarking effective tool for restructuring business", Socio-Economic Recearch Bulletin of ONEU, no. 14, pp. 329-334, 2003. [in Ukrainian].

[6] Doing Business 2019: Training for Reform. World Bank Group, 2019. [Online]. Available: https://www.doingbusiness.org/en/reports/global-reports/doingbusiness-2019. Accessed on: July 02, 2019.

[7] V. Martyniuk, Y. Zvoliak, and O. Baranetska, Financial security. Ternopil, Ukraine: Vector, 2016. [in Ukrainian]

[8] Doing Business. Ministry of Economic Development and Trade of Ukraine, $2019 \quad$ [Online]. Available: http://www.me.gov.ua/Documents/Detail?lang=uk-

UA\&id=232ba380-67ec-4689-a90e-

f67da7840f9e\&title=DoingBusiness. Accessed on: July 05, 2019.
[9] Cabinet of Ministers of Ukraine. (2016, Nov. 23). No 926-p. Action plan on implementation of best practices of qualitative and effective regulation referred to by the World Bank in methodology Doing Business. [Online]. Available: https://zakon5.rada.gov.ua/laws/show/926-2016-p/paran5?lang=en. Accessed on: July 10, 2019. [in Ukrainian].

[10] Statistical information. State Statistics Service of Ukraine, 2019. [Online]. Available: http://www.ukrstat.gov.ua. Accessed on: June 17, 2019

[11] O. Vlasyuk, Actual problems of financial security of Ukraine in conditions of post-crisis transformation. Kiev, Ukraine: NISS, 2014. [in Ukrainian].

[12] S. Onyshchenko, and A. Masliy, "Organizational and economic mechanism of prevention the threats to budget security of Ukrainian economy", Scientific bulletin of Polissia, p. 1, no. 1 (9), pp. 176-184, 2017. [in Ukrainian].

[13] The Ministry of Economic Development and Trade of Ukraine. (2013, Oct. 29). No 1277, On approval of methodological recommendations for calculating the level of economic security of Ukraine. [Online]. Available: http://me.kmu.gov.ua. Accessed on: Apr. 25, 2019. [in Ukrainian].

[14] Monetary data. National Bank of Ukraine, 2019. [Online]. Available: https://www.bank.gov.ua/statistic/sector-financial/data-sectorfinancial. Accessed on: June 17, 2019.

[15] I. Shkolnik et al., Problems and prospects of financial system development of Ukraine. Sumy, Ukraine: Sumy State University, 2017. [in Ukrainian].

[16] Trends in the shadow economy in Ukraine in 2018. The Ministry of Economic Development and Trade of Ukraine, 2019. [Online]. Available: http://www.me.gov.ua/Documents/List?lang=ukUA\&id=e384c5a7-6533-4ab6-b56f-

50e5243eb15a\&tag=TendentsiiTinovoiEkonomiki. Accessed on: July 11, 2019. [in Ukrainian].

[17] Corruption Perceptions Index 2018. Transparency International, 2019. [Online]. Available: https://www.transparency.org/whatwedo/publication/corruption_perce ptions_index_2018. Accessed on: July 12, 2019.

[18] Y. Goncharuk, and M. Fleichuk, "Scales and implications of the spread of the shadow economy and corruption in a globalizing environment", Scientific Herald, Economic series, no. 1, pp.3-18, 2011. 